\title{
The environmental policy implementation of the city of Sochi (Russia)
}

\author{
Anna Balabanova ${ }^{1, *}$, Nadezhda Keschyan ${ }^{1}$, Tatyana Borisova $^{1}$ and Ekaterina \\ Hachemizova $^{1}$ \\ ${ }^{1}$ Sochi State University, ul. Sovetskaya, 26A, 354000, Sochi, Russia
}

\begin{abstract}
The article discusses the structure of city environmental management, regulatory documents, environmental monitoring system, the consequences of environmental policy at the local and regional levels, including cost analysis associated with the implementation of the city's environmental strategies.
\end{abstract}

\section{Introduction}

Man lives among nature and is part of nature, his health and livelihoods are completely connected and dependent on the environment. With the development of technology, the potential impact of humankind on the environment, as well as the parallel growth of the population and the lack of environmental literacy of the majority of the population, environmental problems are not just an urgent topic, but a safety issue for any territory. Also, the ecology of the territory is the basis for such a concept as a quality of life; therefore, environmental policy for state and municipal authorities in modern conditions is a necessity. City ecology is used as an important indicator for assessing and creating a rating of sustainable cities [1].

Despite the modern progress, the problems of environmental policy are still relevant and not resolved, especially for large cities. In modern studies, for example, the reduction of greenhouse gas emissions, the use of renewable energy sources, the use of public transport are still relevant areas of sustainable and social development of the city [2, 3, 4].

When solving these problems, not only technologies are very important, but also how local officials work, since their low level of professionalism can complicate environmental management in these cities [5]. At the same time, in various studies of this issue, the importance of the factor of openness of information and the used methodologies for assessing the state of the ecology of a city are evaluated in different ways [6].

This article raises the question of the results of the environmental policy of the city of Sochi, problems that are relevant to the environmental policy of the city and further development directions.

Consider the consequences of environmental policy at the local level on the example of a resort city of Sochi. The city is located in the south of Russia, on the Black Sea coast and in the foothills of the Caucasus Mountains. This city is interesting from the point of view of

\footnotetext{
*Corresponding author: annabalabanovasochi@gmail.com
} 
the development of environmental policy at the local level, and the growing new environmental problems both at the global and local levels.

\section{Materials and Methods}

The article used the method of theoretical analysis and synthesis of scientific and methodological literature, regulatory documents, observation, methods of mathematical analysis and statistics. The publications were also a source of data for analysis:

- Reports and plans of the Public Environmental Council under the Head of the City of Sochi (Municipal Administration of the City of Sochi, Sochi, 2017);

- "Krasnodar region in numbers". 2017. (Territorial body of the Federal State Statistics Service for the Krasnodar Territory. Krasnodar, 2018);

- "Krasnodar region in numbers". 2016. (Territorial body of the Federal State Statistics Service for the Krasnodar Territory. Krasnodar, 2017);

- "Krasnodar region in numbers". 2015. (Territorial body of the Federal State Statistics Service for the Krasnodar Territory. Krasnodar, 2016);

- Report on the implementation of the Sochi city budget for 2012-2017. (Department for Finance and Budget of the Administration of the City of Sochi, Sochi, 2018);

- Reviews on the level of air pollution, sea water, surface land waters. (Black Sea-Azov Maritime Administration of the Russian Natural Supervision, Sochi, 2018).

\section{Results}

For this city, the impetus for the development of the environmental management system of the territory and the implementation of a focused environmental policy were significant factors:

- environmental policy of the Russian Federation;

- increasing competition in the leading industry of the city of tourism, as well as balneology;

- the holding of the XXII Olympic Winter Games and the XI Paralympic Winter Games of 2014 in the city and the adoption of relevant obligations to comply with environmental requirements and standards;

- holding in the city of the FIFA World Cup 2018 and the adoption of relevant obligations, requirements, standards.

Consider a system of management and monitoring of the ecology of the city. At the municipal level, the city's environmental management system includes:

- The Department of Environmental Protection, Forest Park, Agriculture and Industry of the Sochi City Administration;

- Public Environmental Council under the Head of the city of Sochi;

- functional units of the city administration, in certain functions and powers,

- Municipal enterprises and institutions having a functional orientation (Zelenstroy, Ozelenitel, Committee for Nature Management and Environmental Protection of the City of Sochi, etc.).

The city's environmental monitoring system includes:

- the commission for monitoring the state of the environment of the Ecological Council of the city of Sochi;

- experts and specialists of the Ministry of Natural Resources of the Krasnodar Territory;

- Federal State Budgetary Institution "Specialized Center for Hydrometeorology and Environmental Monitoring of the Black and Azov Seas"; 
- Sochi branch of the federal institution "Center for Hygiene and Epidemiology in the Krasnodar Territory"

- units of the Federal Service for Hydrometeorology and Environmental Monitoring;

- units of the Federal Service for Supervision of Consumer Rights Protection and Human Welfare.

We will also highlight the institutions that monitor and supervise environmental protection in the city of Sochi:

- The Federal Service for Supervision of Consumer Rights Protection and Human Welfare;

- The Office of the Federal Service for Supervision of Natural Resources in the Krasnodar

Territory and the Republic of Adygea;

- Ministry of Natural Resources of Krasnodar Region

- Sochi Interdistrict Environmental Prosecutor's Office;

- Black Sea-Azov Maritime Administration of the Russian Natural Supervision.

The main regulatory documents in which the city's environmental policy is implemented:

- The environmental municipal program "Resort City of Sochi" "Preservation of Natural, Historical and Cultural Heritage (2015-2030)";

- The concept of sustainable development of the city of Sochi until 2030;

- The strategy of investment development of the municipality of the resort city of Sochi until 2020;

- Municipal target program of the city of Sochi "Improvement of the territory of the municipality of the resort city of Sochi";

- Federal concepts of national, demographic, environmental policy of the Russian Federation;

- national strategy for the conservation of biodiversity;

- obligations of Russia under relevant international conventions and federal legislation of Russia in the field of ecology.

Let us consider in more detail the activities in the field of ecology of the main executive division of the city administration Department for Environmental Protection, Forest Park, Agriculture and Industry of the City of Sochi:

- Organization of the development and implementation of the Sochi city policy in the field of environmental management and environmental protection.

- Preparation of proposals and measures aimed at improving the environmental system.

- Organization of the development and implementation of environmental protection measures.

- Conducting organizational measures for the preservation of existing natural objects and the construction of new objects of municipal gardening in the city of Sochi.

- Organizing the collection of systematization and analysis of information about the source and nature of the impact on the environment.

- Organization of the preparation of targeted programs and action plans for environmental protection, ecological development of the city of Sochi and landscaping.

- Promoting the involvement of research institutions in the development of scientific topics on environmental protection, park building and landscaping.

- Facilitating the training and retraining of specialists in landscaping and flowers.

- Promotion of urban environmental exhibitions and flower shows.

- Consideration of appeals of individuals and legal entities related to the use of natural resources of local importance, environmental protection, maintenance and protection of the green fund of the city of Sochi, within the limits of authority determined by applicable law. - Informing the population about the situation in the city of Sochi on landscaping. 
- Considers, organizes and monitors the implementation of legal and regulatory instructions on the use of natural resources of local importance, environmental protection within the powers of local governments.

There is a fairly wide scope of activities, but very little information in public access about the events that are actually being held, the degree of implementation of the above functions of this department.

Another significant participant in the environmental policy of the city is the permanent Public Environmental Council under the Head of the City of Sochi, which was established by the Decree of the Head of the City of Sochi dated November 18, 2015 No. 3237. The Council included representatives of the public of the City of Sochi, researchers, specialists in various fields related to environmental protection, also employees of local governments. The Council acts as an advisory center focused on the development of the Greater Sochi agglomeration on the basis of the principle of sustainable development; the disclosure of the recreational potential of the territory and the qualitative improvement of the life of the population.

The following commissions were formed under the Council:

- Commission on green space; (at the commission on green plantings a working group was formed);

- Commission on specially protected natural territories;

- Commission for engineering and environmental safety;

- Committee for monitoring the state of the environment;

- Commission for the preservation of natural and historical and cultural heritage.

The activities of this Council are more public, there are published work plans from 2016 to 2018, as well as the minutes of the meeting of the Environmental Council. Approved and published rules of the Council. This council conducts activities, there are results, but there is no system of indicators evaluating results, a system for measuring performance.

Also, an important part of the environmental policy is environmental monitoring, the purpose of which is to assess the observed changes in the environment and to identify the effect of human activity, forecast the expected changes in the environment, and develop optimal solutions to prevent negative consequences of human activity.

It should be noted that the Commission on Environmental Monitoring of the aforementioned Public Ecological Council under the Head of the City of Sochi held 10 working sessions involving experts and specialists from the Ministry of Natural Resources of the Krasnodar Territory, the Administration of the City of Sochi, the Roshydromet subdivision, and the Sochi Branch of the Center for Hygiene and Epidemiology in the Krasnodar Territory. Based on the results of these meetings and the study of the activities of the participants in the monitoring system, the following can be determined:

1. The city monitors the pollution of individual environmental objects within the framework of its own goals and objectives by units of a number of federal services;

2. "The Center for Hygiene and Epidemiology in the Krasnodar Territory" conducts seasonal (during the holiday season) monitoring of the sanitary and epidemiological status of sea waters in the coastal (beach) zone on the main beaches of the city, as well as regular monitoring of the quality of surface waters. on separate water bodies;

3. By 2014, the "Environmental Monitoring System of the Black Sea Coast of the Caucasus" was created. The system is designed for integrated environmental monitoring and was developed to obtain information on the state of the environment during the preparation, holding and after the XXII Olympic Winter Games and XI Paralympic Winter Games of 2014 in the city of Sochi, including the territory of the Sochi National Park, as well as the nearby facility UNESCO World Heritage Site "Western Caucasus". Within the system, monitoring of the quality of all components of the environment is organized. System composition: 
- Automatic stations for monitoring air pollution in the areas of the Olympic Games and residential areas -6 pcs.

- Automatic points of control of the atmosphere in the areas of construction of Olympic facilities -3 pcs.

- Mobile environmental monitoring laboratory of the atmosphere - 2 pcs. and mobile hydrochemical laboratory - 1 pc. for regular sampling in hard-to-reach places and on special routes.

-Automatic water control stations - 2 pcs.

- Center for the collection and processing of information, representing real-time data from the elements of the system operating in automatic mode.

4. The "Specialized Center for Hydrometeorology and Environmental Monitoring of the Black and Azov Seas", within the framework of a state task, monitors environmental pollution in order to determine its background condition. The main purpose of background monitoring is to ascertain and fix indicators that characterize the natural background (the state of the natural environment, which has not experienced the direct influence of human activity). Regular monitoring of the quality of atmospheric air at stationary posts, sea water in coastal and conditionally clean zones and surface water at a number of water bodies is carried out.

However, given all the above activities and the availability of equipment, the collection of the necessary data can highlight common problems:

- no synthesis of the obtained data and presentation in the form of a single information product, as well as the prediction of environmental pollution, are not made;

- open public access to data for research and analysis is not provided;

- observations are not made in conditionally clean (background) sections, which are the least subject to anthropogenic impact and are of interest from the point of view of the sanitary and epidemiological well-being of the population;

- not to set a task and not to analyze monitoring data in order to identify the source of pollution, which is the most pressing issue for strategic management and environmental policy in the framework of the concept of sustainable development of the territory.

In the main strategic documents of the city, separate directions in ecology are not distinguished, just as a separate task, environmental policy is found in the system of housing and communal services, transport, infrastructure, etc. (for example, in the strategy of investment development of the city until 2020, the indicative plan of the city for 2018 and the planned period until 2020, the socio-economic plan of the city and others). Separate attention, as a whole direction and an important factor for the development of the city, is paid to environmental issues in the concept of sustainable development of the city of Sochi until 2030, which was developed based on international standards and obligations of the city to the International Olympic Committee.

Therefore, the main strategic document of the city within the framework of environmental policy can be identified the environmental program "Resort City of Sochi" "The preservation of natural and historical and cultural heritage (2015-2030 gg.)."

The environmental program of the resort city of Sochi is based on the resolution of the regional conference "Post-Olympic Sochi. Ecological problems and prospects for preserving the natural and historical-cultural heritage" (05.06.2014), the Ecological Forum (05.06.2014), methodological developments of the Sochi Scientific Center of the Russian Academy of Sciences and the Sochi city department of the Russian Geographical Society.

The goal of the program is to coordinate the activities of the expert community, environmental organizations, civil institutions, municipal authorities and territorial selfgovernment bodies aimed at a comprehensive solution of environmental, socio-economic and ethnocultural problems on the territory of the municipal city of Sochi. Over the next fifteen years, the program will contribute to improving the ecological, socio-economic and 
ethnocultural situation, implementing projects aimed at researching, promoting, preserving and using natural and historical-cultural heritage monuments, participating scientific, educational, environmental organizations and civil society institutions in developing and the introduction of innovative technologies of territorial management.

This document does not have a clear plan for the implementation of the program, does not provide for the timing of activities, there are no specific parameters and indicative indicators, according to which it is possible to evaluate their effectiveness and expediency of the activities and the overall implementation of the entire program. It also has the problem of public control, the responsibility of participants for the fulfilment of their obligations and the availability of reporting documents on the work carried out in the public domain.

Within the framework of the municipal target program of the city of Sochi "Improvement of the territory of the municipality of the resort city of Sochi", the goal has been set to increase the comfortable living conditions of citizens, ensure environmental well-being, improve the sanitary and aesthetic condition of the territory of the city of Sochi. To achieve this goal, the task is to "improve the efficiency of use, protection, protection and reproduction of greenery to maintain a favourable environment and living conditions of the population".

Table 1. The volume and structure of financing of the municipal target program of the city of Sochi "Improvement of the territory of the municipality of the resort city of Sochi", thousand rubles.

\begin{tabular}{|c|c|c|c|c|c|}
\hline \multirow{2}{*}{$\begin{array}{c}\text { Year of } \\
\text { impleme } \\
\text { ntation }\end{array}$} & \multirow[b]{2}{*}{ Total } & \multicolumn{4}{|c|}{ In terms of sources of financing } \\
\hline & & federal budget & $\begin{array}{c}\text { regional } \\
\text { budget }\end{array}$ & $\begin{array}{l}\text { budget of the } \\
\text { city of Sochi }\end{array}$ & $\begin{array}{c}\text { extrabudgetary } \\
\text { sources }\end{array}$ \\
\hline 1 & 2 & 3 & 4 & 5 & 6 \\
\hline \multicolumn{6}{|c|}{ Main events } \\
\hline \multirow{3}{*}{2016} & 454359.9 & 0 & 0 & 454359.9 & 0 \\
\hline & 505.7 & 0 & 0 & 505.7 & 0 \\
\hline & 711.9 & 0 & 0 & 711.9 & 0 \\
\hline \multirow{2}{*}{2017} & 527225.2 & 0 & 500 & 526725.2 & 0 \\
\hline & 5048.5 & 0 & 0 & 5048.5 & 0 \\
\hline 2018 & 521071.6 & 0 & 700 & 520371.6 & 0 \\
\hline 2019 & 487341.7 & 0 & 0 & 487341.7 & 0 \\
\hline 2020 & 487341.7 & 0 & 0 & 487341.7 & 0 \\
\hline 2021 & 393214.5 & 0 & 0 & 393214.5 & 0 \\
\hline
\end{tabular}

In the task "improving the efficiency of use, protection, protection and reproduction of greenery to preserve a favorable environment and living conditions of the population", the activities "Greening the territory of the city of Sochi" and "Sanitary cleaning of the territory of the city of Sochi" are highlighted within which activities are carried out to improve the territory: landscaping squares, parks; maintenance of green spaces, pedestrian areas; demolition and maintenance of emergency trees; planting flower seedlings in flower beds; chemical plant protection against pests and diseases; preventive treatment (pest control), squares and parks; shelter for the winter and the disclosure of heat-loving plants; planting and maintenance of plants, hedges, trees, palm trees, and shrubs, and so on.

The activities of the "Sanitary cleaning of the territory of the city of Sochi" mainly include trapping of homeless animals; sanitary cleaning of the territory from unauthorized piles of garbage, selection of dead animals.

Consider the amount of funding for these activities in the financing structure of the municipal target program: 
Table 2. The amount of funding for activities "Greening the territory of the city of Sochi" and "Sanitary cleaning of the territory of the city of Sochi" of the municipal target program of the city of Sochi "Improvement of the territory of the municipal formation of the resort city of Sochi" 20162021, thousand rubles.

\begin{tabular}{|l|c|c|}
\hline \multicolumn{1}{|c|}{ Name of events } & Total & $\begin{array}{c}\text { Share in total } \\
\text { program funding }\end{array}$ \\
\hline $\begin{array}{l}\text { The main event "Greening the territory of the city of } \\
\text { Sochi" }\end{array}$ & 984081.3 & $34 \%$ \\
\hline $\begin{array}{l}\text { The main event "Sanitary cleaning of the territory of } \\
\text { the city of Sochi" }\end{array}$ & 89082.9 & $3 \%$ \\
\hline
\end{tabular}

When considering directly the activities and costs in each direction, the main expenses are to decorate the city and maintain the number of green spaces.

When considering directly the activities and costs in each direction, the main expenses are to decorate the city and maintain the number of green spaces.

Let us analyze the results of the environmental policy of the city over the past few years.

To achieve the goals set in 2008, a program of activities was developed for the environmental support of the preparation and holding of the XXII Olympic Winter Games and the XI Paralympic Winter Games of 2014 in the city of Sochi. In 2009, the Sochi 2014 Environmental Strategy was approved for the organization of the Green Winter Olympics in the city.

In preparation for the Olympics, environmental problems that had been accumulated over the years were solved. With the assistance of the Public Chamber of the City of Sochi, and to improve the environmental situation, the landfill for solid household waste in Adler was closed. Now it is in a mothballed state and is under the control of the municipal enterprise "Vodostok". As part of the Olympic program, specialists subjected the landfill of solid household waste to deep processing and brought it into an environmentally safe state. The body of the landfill is covered with a waterproofing layer. The bypass channels for rainwater runoff make it dry and the treatment plant safe. Gas-burning equipment and membranes exclude the possibility of ingress of harmful impurities into the air and the river.

Also under the "zero waste" program, the municipal solid waste landfill in Loo was also shut down. As part of its recultivation, commissioned by the "Main Directorate for Construction of the Krasnodar Territory", a whole range of activities were carried out, including construction and assembly works, and terracing. Special systems for degassing, collecting and cleaning the filtrate were installed, and a technological road was laid along the perimeter of the fenced area.

In general, the resort has plans to build a waste incineration plant that will minimize the costs of garbage collection and at the same time make the process of destruction of household waste environmentally sound. But this has been in the plan for several years now, and so far, there has been no real action to implement the plan.

In addition, work was carried out on gardening, preservation of flora and fauna on the territory of Greater Sochi. As part of the Olympic construction, compensatory tree planting was carried out.

Four systems of "green" construction standards that meet international requirements have also been introduced. "Green standards" of construction, focused on energy and environmental efficiency; the environmental management system implemented at the Olympic facilities on the basis of the international standard ISO 14001: 2009 and the increased environmental awareness of the residents of the Sochi region.

If we talk about construction in the mountains, which attracted the special attention of environmentalists, it is important to note that the area occupied by all sports facilities of the 
mountain cluster is 2000 hectares, which does not exceed $1 \%$ of the total area of the Sochi National Park. As for the construction of facilities in the Imeretinskay Valley, with their construction, a powerful system of engineering protection was created at the same time.

When designing the Olympic Park, the possibility of a circulating water supply system, the collection and use of rainwater was provided, thermal energy storage systems were used to condition the facilities, and carbon dioxide emissions to the atmosphere were minimized. Much has been done to reduce the amount of wastewater discharged into the Black Sea, water supply systems have been reconstructed, four new water intakes have been built.

The Department of Environmental Protection, Forest Park, Agriculture and Industry of the Sochi City Administration has been established, which has been assigned tasks and powers in environmental policy. Also in 2015, the Public Environmental Council was created under the Head of the City of Sochi, which allows you to create a unified city environmental management system of the city, involving in these processes different participants in city life.

In the structure of the budget expenditures of the city of Sochi on the direction of "Environmental Protection" there are the following items of expenditure:

- Protection of flora and fauna objects and their habitats;

- Environmental protection, reproduction and use of natural resources;

- Non-program costs for the implementation of environmental protection, reproduction and use of natural resources;

- Ensuring the activities of municipal institutions;

- The costs of the activities (services) of municipal institutions;

- Expenses for payments to staff in order to ensure the fulfillment of functions by state (municipal) bodies, state institutions, management bodies of state extra-budgetary funds (Expenditures on payments to personnel of state (municipal) institutions, the Fund for labor of institutions, other payments to personnel of institutions, except for the fund for labor, contributions for compulsory social insurance for remuneration of employees and other payments to employees of institutions);

- Purchase of goods, works and services for state (municipal) needs;

- Social security and other payments to the population (Social payments to citizens, except public normative social payments, Benefits, compensations and other social payments to citizens, except public normative obligations, Other budget allocations);

- Payment of taxes, fees and other payments (Payment of property tax organizations and land tax, the Payment of other taxes, fees).

The direction "Environmental Protection" in the budget of the city of Sochi in 2017 was allocated 3,895 thousand rubles, which is less than the average value of funding over the past 5 years $-5,478.54$ thousand rubles, and amounted to $0.03 \%$ of the total city budget.

Table 3. The amount of financing of the section "Environmental Protection" of the budget of the city of Sochi for 2012-2017, thousand rubles.

\begin{tabular}{|c|c|c|c|}
\hline Name & $\begin{array}{c}\text { Total budget (total), } \\
\text { thousand rubles }\end{array}$ & $\begin{array}{c}\text { Environmental protection, } \\
\text { thousand rubles }\end{array}$ & $\begin{array}{c}\text { Share in total } \\
\text { expenses, } \%\end{array}$ \\
\hline 2017 year & 13852568 & 3895 & $0.03 \%$ \\
\hline 2016 year & 11929078 & 5183 & $0.04 \%$ \\
\hline 2015 year & 11933199 & 5927 & $0.05 \%$ \\
\hline 2014 year & 12416511 & 6125 & $0.05 \%$ \\
\hline 2013 year & 19968112 & 5845 & $0.03 \%$ \\
\hline 2012 year & 19269122 & 5896 & $0.03 \%$ \\
\hline
\end{tabular}

As can be seen (see table 4), in terms of the budget of the city of Sochi for 2018 and the planned period of 2019-2020, presented by the Department of Finance and Budget of the city of Sochi, it is planned to reduce funding for environmental protection in monetary 
units, but relative to the volume of the city budget will increase the proportion of these costs.

Table 4. The financing plan for the section "Environmental Protection" of the budget of the city of Sochi for 2018-2020, thousand rubles.

\begin{tabular}{|c|c|c|c|}
\hline Name & $\begin{array}{c}\text { Total budget (total), } \\
\text { thousand rubles }\end{array}$ & $\begin{array}{c}\text { Environmental } \\
\text { protection, thousand } \\
\text { rubles }\end{array}$ & $\begin{array}{c}\text { Share in total } \\
\text { expenses, } \%\end{array}$ \\
\hline $\begin{array}{c}2020 \text { year } \\
\text { (plan) }\end{array}$ & 10451100 & 3750 & $0.04 \%$ \\
\hline $\begin{array}{c}2019 \text { year } \\
\text { (plan) }\end{array}$ & 10246300 & 3750 & $0.04 \%$ \\
\hline $\begin{array}{c}2018 \text { year } \\
\text { (plan) }\end{array}$ & 10621600 & 3750 & $0 . .03 \%$ \\
\hline
\end{tabular}

As a result, if we analyze the dynamics of financing city expenditures on the environment, then the highest volumes of funds were financed in 2014-2015. In the same period, the share of environmental expenses in the total budget of the city also reached its maximum of $0.05 \%$.

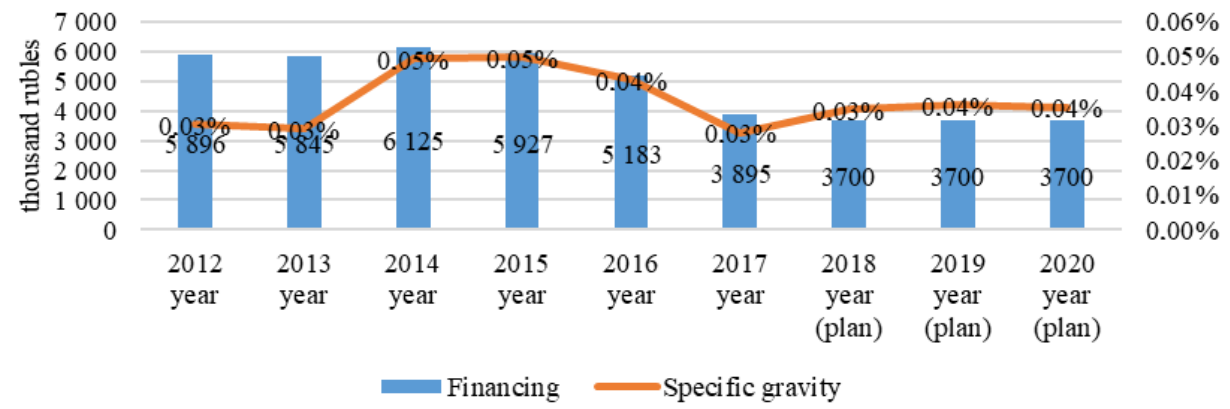

Fig. 1. The dynamics of expenditures of the budget of the city of Sochi for environmental protection in 2012-2017 and plan for 2018-2020, thousand rubles.

The last 3 years there has been a decrease in funding, both in terms of money and in terms of the significance of these expenses in the budget.

Consider how the environmental indicators of the city of Sochi have changed during the implementation of environmental policies. According to the federal state statistics service, emissions, capture and disposal of pollutants in the city of Sochi in 2016 increased by 300 tons compared with 2015 , as well as the quality and $\%$ of the captured and neutralized substances decreased.

Table 5. Emissions, capture and disposal of polluting substances of the city of Sochi for 2015-2016, thousand tons.

\begin{tabular}{|c|c|c|c|c|c|}
\hline \multirow{3}{*}{ Period } & \multirow{3}{*}{$\begin{array}{l}\text { The amount of } \\
\text { pollutants emitted } \\
\text { from stationary } \\
\text { sources }\end{array}$} & \multicolumn{4}{|c|}{ of them caught and rendered harmless: } \\
\hline & & \multirow[b]{2}{*}{ Total } & \multirow{2}{*}{$\begin{array}{l}\text { as a percentage of } \\
\text { the number of } \\
\text { contaminants }\end{array}$} & \multicolumn{2}{|c|}{ of which utilized: } \\
\hline & & & & Total & $\begin{array}{c}\text { as a percentage of } \\
\text { caught }\end{array}$ \\
\hline 2016 year & 7.3 & 1.8 & 25.4 & 1.5 & 78.9 \\
\hline 2015 year & 7 & 1.8 & 26 & 1.8 & 100 \\
\hline
\end{tabular}

Among the cities of the region and municipal districts, the city shows an average value and is not the most positive (Figure 2). In the presented Figure 2, the city of Novorossiysk 
is not included, in which the volume of emissions of substances make up $81 \%$ of the total volume in the Krasnodar Territory (1234.3 thousand tons for 2016).

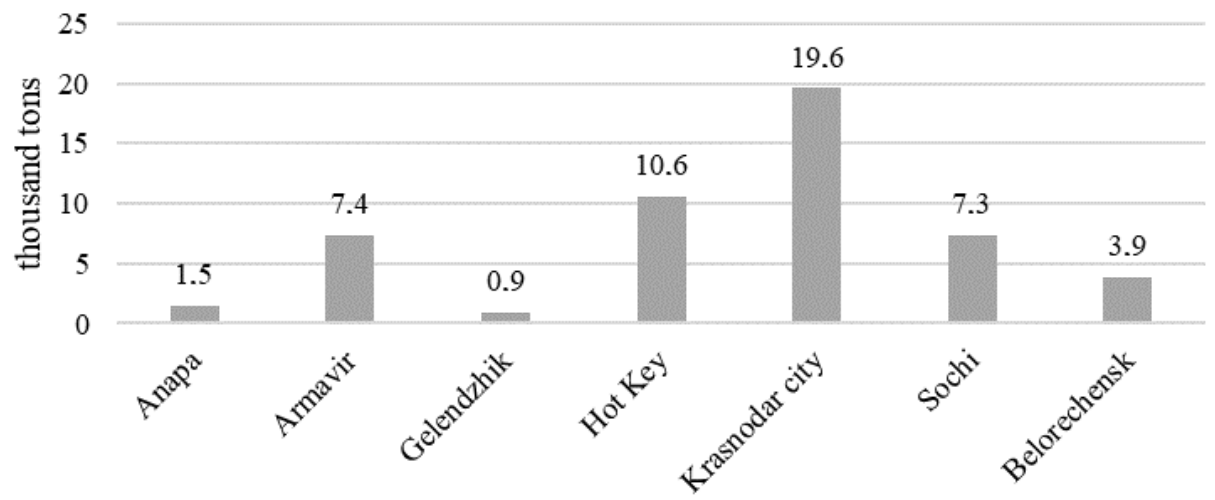

Fig. 2. Emissions, capture and disposal of polluting substances of cities of the Krasnodar Territory for 2016, thousand tons.

Against the background of the general dynamics of atmospheric emissions of the most common pollutants coming from stationary sources in the region, the growth rates of pollutants in the city of Sochi are quite low (Fig. 3.).

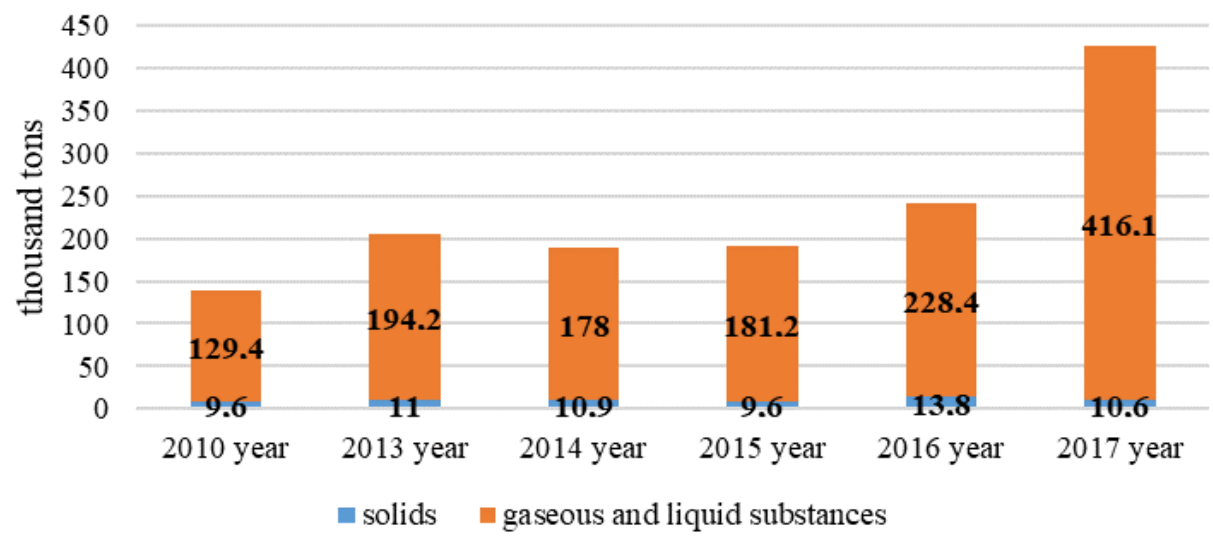

Fig. 3. Dynamics of atmospheric emissions of the most common pollutants from stationary sources in the Krasnodar Territory for 2010-2017, thousand tons.

Let us consider in more detail the quality of atmospheric air, the quality of sea waters and the quality of surface waters, which are monitored as part of the environmental monitoring of the city of Sochi. The level of air pollution in Sochi is mainly determined by emissions from motor vehicles, which constitute more than $80 \%$ of the total amount of pollutants supplied. The main contribution to emissions from stationary sources is housing and utilities enterprises and energy.

Analysis of the level of air pollution over a 5-year period.

In the period from 2013, the maximum average annual content of suspended substances was noted in 2014, after which in 2015 and 2016 it remained almost unchanged. In 2017, there was a decrease to a level that was $12 \%$ lower than the 2013 figure. The total pollution of the atmosphere of the city compared with 2013 decreased. Thus, in the last 5 years, there has been a steady trend towards the purification of the atmospheric air of Sochi and the 
achievement of the average statistics of the pre-Olympic years, which is apparently a consequence of the measures taken to improve the city's road infrastructure, the use of better fuel in motor vehicles.

Analysis of trends in changes in the quality of marine waters over a 5-year period. The average annual content of most of the controlled impurities remained significantly below the established norms. In 2015-2016 there were slight deviations from the norm. Also, predominantly at the estuarine stations, single violations of the requirements for the content of petroleum products, nitrite nitrogen, synthetic surfactants and easily oxidizable organic substances were noted. In recent years, the content in mercury of sea water in dissolved form has significantly decreased. Since 2008, the lead content has steadily increased, reaching a maximum in 2015 , after which a steady decline was observed.

Analysis of surface water pollution in the resort city of Sochi in 2017. According to the results of observations in 2017, the water quality of the monitored water bodies meets the following quality criteria: Laura River is "slightly polluted"; Mzymta River - "polluted"; Khosta River - "slightly polluted"; The Sochi river within the city is characterized as "slightly polluted", in the upper reaches of the river it is also "slightly polluted", the Psezuapse river is "slightly polluted". Compared to 2016, the quality class increased in the rivers of Sochi (within the city), Laura and Khosta, in the Mzymta river, on the contrary, decreased, in other river stations it remained at the same level. The average coefficient of complexity slightly increased in the Mzymta and Psezuapse rivers. The multiplicity of exceeding the standards indicates the average level of water pollution in all observed rivers during the year. Cases of high and extremely high pollution in 2017 were not recorded.

The main anthropogenic sources of pollution of the rivers and the coastal zone of the Black Sea are unorganized economic, domestic and storm runoff of settlements, washings from catchment areas, rainwater flows from the territories of enterprises of the city and highways, tourist load in the summer-autumn period. The quality of river water is also influenced by utilities, sanatorium and construction industries.

\section{Discussion}

As a result of the analysis, the quality of the environment in the city of Sochi is deteriorating: for some components (air) gradually, for others (biodiversity, landscapes, the state of the waters) - in a progression.

But the changes are not significant. In general, if we consider the last decade, the environmental policy and its financing led to the improvement of most environmental indicators and slowed down the deterioration of the environmental situation in the territory, especially against the background of population growth and industry. The following problems still remain relevant: an increase in the area of landslide plots; reduction of green spaces and horticultural areas within the city; changes in coastal ecosystems, seawater quality in the coastal zone of the city; increasing anthropogenic impact on coastal and mountain landscapes (migration); the expansion of the range of alien phytophagous invader species; the narrowing of areas of distribution of vegetation species listed in the Red Book.

To improve the situation, it is necessary to look for new methods. These problems are characteristic of many territories. But is it possible to improve environmental management processes without innovative technologies and costly solutions? This question is relevant since not all cities have access to innovative technologies and resources [7]. 


\section{Conclusions}

Let us highlight the main problems that need to be solved in the city's environmental policy system: an insufficiently efficient system of interaction between government bodies, environmental organizations and civil society institutions, the lack of sustainable sources of funding for scientific and applied research and projects aimed at solving environmental problems, insufficient control in the system wastewater collection and treatment; the absence of an open system for monitoring and controlling the state of the sea beach zones for their compliance with the standards of the corresponding international rating system.

The development of the city's environmental policy requires: the availability and openness of reporting information on the city's environmental indicators, clear plans, deadlines, and indicators for the implementation of activities, a municipal environmental program is required, public responsibility of program implementers, the creation of a single information center for all environmental activities, the creation of the concept of sustainable development of the territory of the "Big Sochi".

It is also necessary to consider the development of technologies and standards of green building for the urban construction industry based on nanotechnology products [8].

It is possible to consider 4D BIM for environmental planning and city management. Constant attention to environmental impacts based on construction provides an incentive to use 4D BIM to improve information sharing and information flow in environmental planning and management tasks [9].

\section{References}

1. A. Akande, Sustainable Cities and Society 44, 475-487 (2019)

2. A. Petit-Boix, S. Leipold, Journal of Cleaner Production 195, 1270-1281 (2018)

3. M.H. Dehghani, Data in Brief 20, 258 - 268 (2018)

4. M. Liikanen, Journal of Cleaner Production 196, 150 - 162 (2018)

5. Huiming Zhang, Energy Procedia 143, 873-879 (2017)

6. N. Mirabella, K. Allacker, Procedia Environmental Sciences 38, 635 - 642 (2017)

7. K. Axelsson, M. Granath, Government Information Quarterly 35, 693-702 (2018)

8. V. Telichenko, Procedia Engineering 153, 726 - 730 (2016)

9. J. Jupp, Procedia Engineering 180, 190 - 201 (2017)

10. N. Panya, Kasetsart Journal of Social Sciences 39, 33-41(2018) 